University of Nebraska - Lincoln

DigitalCommons@University of Nebraska - Lincoln

September 2004

\title{
Curtius rearrangement and Wolff homologation of functionalized peroxides
}

\author{
Patrick Dussault \\ University of Nebraska-Lincoln, pdussault1@unl.edu \\ Chunping $\mathrm{Xu}$ \\ University of Nebraska - Lincoln
}

Follow this and additional works at: https://digitalcommons.unl.edu/chemistrydussault

Part of the Chemistry Commons

Dussault, Patrick and Xu, Chunping , "Curtius rearrangement and Wolff homologation of functionalized peroxides" (2004). Patrick Dussault Publications. 4.

https://digitalcommons.unl.edu/chemistrydussault/4

This Article is brought to you for free and open access by the Published Research - Department of Chemistry at DigitalCommons@University of Nebraska - Lincoln. It has been accepted for inclusion in Patrick Dussault Publications by an authorized administrator of DigitalCommons@University of Nebraska - Lincoln. 
Published in Tetrahedron Letters 45:40 (September 27, 2004), pp. 7455-7457. doi:10.1016/j.tetlet.2004.08.059 Copyright ( 2004 Elsevier Ltd. Used by permission. http://www.sciencedirect.com/science/journal/00404039

Submitted July 2004; revised August 2004; accepted August 9, 2004; published online August 27, 2004.

\title{
Curtius rearrangement and Wolff homologation of functionalized peroxides
}

\author{
Patrick H. Dussault* and Chunping Xu \\ Department of Chemistry, University of Nebraska-Lincoln, Lincoln, NE 68588-0304 \\ *Corresponding author: pdussault1@unl.edu
}

\begin{abstract}
The Curtius and Wolff rearrangements of peroxide-containing alkanoyl azides and diazoketones provide an efficient entry to peroxy-
\end{abstract} substituted amines, isocyanates, carbamates, and peroxyalkanoates.

\section{Introduction}

Synthetic approaches to peroxides are typically constrained by the limited methodology available for introduction of the peroxide functional group. ${ }^{1}$ For example, our recent investigations into redox-based enzyme inactivators ${ }^{2}$ required preparation of 2-peroxyl and 3-peroxylalkylamines, poorly explored functional motifs. ${ }^{3} \mathrm{We}$ now report the successful Curtius rearrangement of peroxyalkanoyl azides as a method for synthesis of peroxysubstituted isocyanates, amines, and carbamates. In addition, we discovered that the corresponding Wolff rearrangement of peroxide-containing diazoketones provides a very effective method for homologation of peroxyalkanoates (Scheme 1).

Preparation of peroxyalkanoic acid substrates is illustrated in Scheme 2. ${ }^{\dagger}$ The synthesis of substrate $4 \mathbf{a}$ includes the first example of acid-catalyzed intermolecular reaction of a hydroperoxide with a secondary epoxide, a reaction that was found to proceed with only moderate regioselectivity in favor of the more substituted peroxide. ${ }^{4}$

\footnotetext{
${ }^{\dagger}$ All new compounds were purified to homogeneity and characterized by ${ }^{1} \mathrm{H},{ }^{13} \mathrm{C}$, IR, and HRMS, except for $\mathbf{1 d}-\mathbf{4 d}$, where no molecular ions were observed.
}

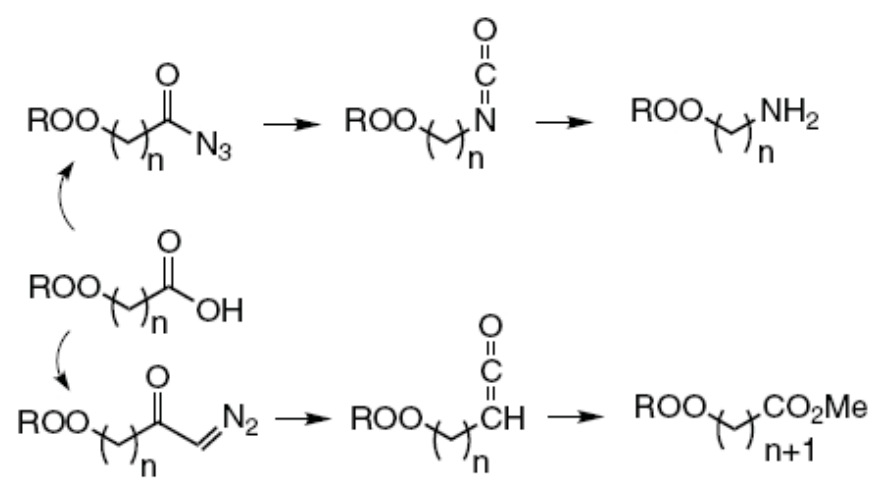

Scheme 1. Curtius and Wolff rearrangements on peroxidic substrates.

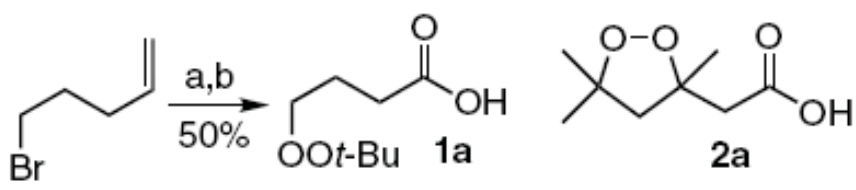

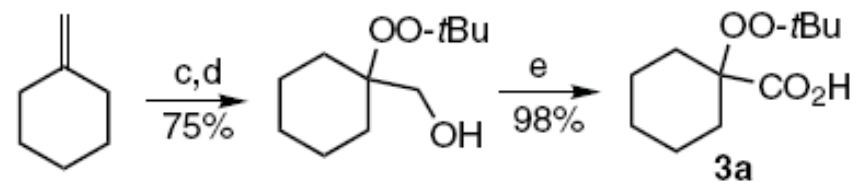

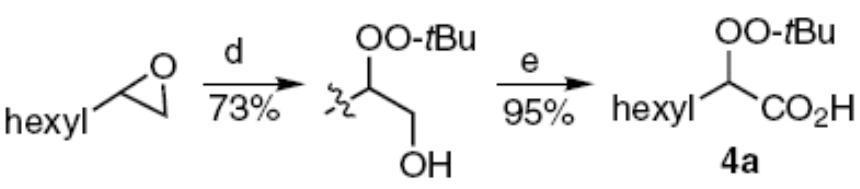

Scheme 2. Substrate preparation. Reagents and conditions: (a) $t$ $\mathrm{BuO}_{2} \mathrm{H}, \mathrm{CsOH}$; (b) $\mathrm{KMnO}_{4}$; (c) $m$-CPBA; (d) $t-\mathrm{BuO}_{2} \mathrm{H}, \mathrm{BF}_{3} \mathrm{OEt}_{2}$; (e) $\mathrm{H}_{2} \mathrm{CrO}_{4}$. 


\section{Curtius rearrangements}

Conversion of the peroxyalkanoic acids to acyl azides was readily achieved via the mixed anhydrides, with the exception of the hindered acid 3a, which required activation as the acid chloride (Table 1). ${ }^{5}$ The azides were stable to extractive isolation but decomposed upon attempted purification. Heating the crude azides with ethanol in refluxing benzene directly furnished the ethyl carbamates $\mathbf{1 b}, \mathbf{2} \mathbf{b}$, and 4b as stable products. In the case of the hindered azide derived from 3a, thermolysis resulted in decomposition with loss of the peroxide functional group. ${ }^{6}$

We also briefly investigated aprotic thermolysis of an azide as an approach to a peroxide-containing isocyanate. Refluxing the acyl azide derived from 2a in dry benzene furnished a dioxolane isocyanate, which was not isolated but which could be observed by IR (Scheme 3). Hydrolysis of the isocyanate in aqueous acid furnished the aminomethyl dioxolane 5, which underwent coupling with CBZ-Phe to furnish a peroxide-containing amino acid $\mathbf{6}$.

\section{Wolff rearrangement}

The success of the Curtius rearrangements described above led us to consider the potential of the Wolff rear-

Table 1. Curtius rearrangement of peroxylalkanoyl azides

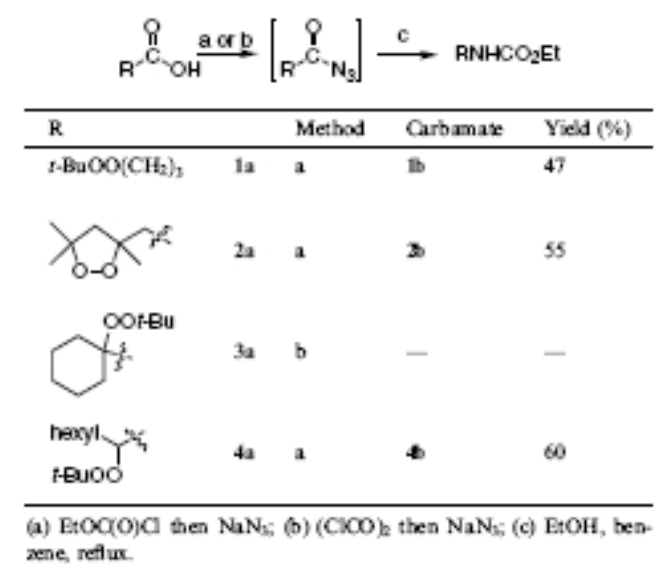

(a) EtOC(O)Cl then $\mathrm{NaN}_{3}$; (b) $(\mathrm{ClCO})_{2}$ then $\mathrm{NaN}_{3}$; (c) EtOH, benzene, reflux.

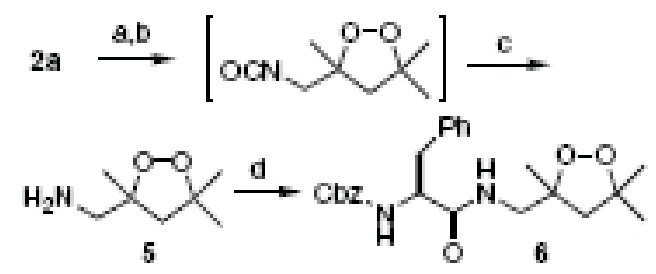

Scheme 3. Synthesis of dioxolane isocyanate and aminomethyl dioxolane. Reagents and conditions: (a) EtOC(O)Cl then $\mathrm{NaN}_{3}$; (b) $\mathrm{C}_{6} \mathrm{H}_{6}$, reflux; (c) aq $\mathrm{HCl}$; (d) CBZ-Phe, DCC.
Table 2. Homologation via diazoketones

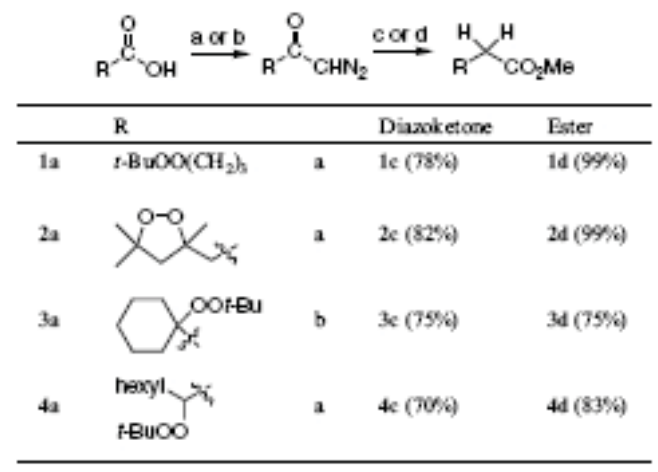

(a) EtOCOOJOl then $\mathrm{CH}_{2} \mathrm{~N}_{2}$; (b) $\mathrm{ClOOCOCl}$ then $\mathrm{CH}_{2} \mathrm{~N}_{2}$; (c) $\mathrm{AgOBz}$ (0.lequiv), Et ${ }_{3} \mathrm{~N}, \mathrm{MeOH}$; (d) hr, MeOH, HOAc.

(a) $\mathrm{EtOC}(\mathrm{O}) \mathrm{Cl}$ then $\mathrm{CH} 2 \mathrm{~N} 2$; (b) $\mathrm{ClCOCOCl}$ then $\mathrm{CH} 2 \mathrm{~N} 2$; (c) $\mathrm{AgOBz}$ (0.1 equiv), $\mathrm{Et} 3 \mathrm{~N}, \mathrm{MeOH}$; (d) hv, $\mathrm{MeOH}$, HOAc.

rangement for preparation of peroxyalkanoates, a functional motif found in a number of marine natural products. ${ }^{7}$ As shown in Table 2, the peroxyalkanoic acids were easily converted, via the mixed anhydrides or the acid chlorides, to isolable diazomethyl ketones. Reaction of diazoketones 1c or $2 \mathrm{c}$ with silver benzoate and triethylamine in methanol furnished the homologated peroxyalkanoates $\mathbf{1 d}$ or $\mathbf{2 d}$ in excellent yield. ${ }^{8}$

Application of these conditions to substrate $\mathbf{4 c}$ resulted in a poor yield of homologated product, accompanied by significant amounts of the oxodiazoketone, apparently derived from base-promoted decomposition of the starting material (Eq. 1). ${ }^{9}$ Photochemical Wolff rearrangement $(254 \mathrm{~nm}$, methanol) furnished a much better yield of the homologated peroxyalkanoate $\mathbf{4 d}$, accompanied by small amounts of 2,3-epoxynonanoate, which presumably arises via intramolecular attack of a developing ester enolate on the peroxide. Performing the photochemical rearrangement in the presence of a trace amount of acetic acid resulted in an improved yield of peroxyalkanoate. The tertiary peroxide substrate 3c, which failed to give any homologation product in the presence of $\mathrm{AgOBz} / \mathrm{Et}_{3} \mathrm{~N}$, underwent photochemical rearrangement to afford peroxyalkanoate $\mathbf{3 d}$.

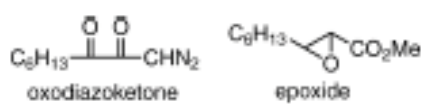

In conclusion, we have demonstrated the ability to employ the Curtius and Wolff rearrangements for synthesis of peroxylamines or homologated peroxyalkanoates. The ability to homologate 2- and 3-peroxyalkanoic acids holds particular promise for synthesis of peroxide natural products while the ability to perform the Curtius rearrangement opens new possibilities for the introduction of natural or unnatural peroxide-containing groups onto polymers and biomolecules. 


\section{Caution}

While we experienced no particular problems, any research involving peroxides, azides, and similar functional groups should be conducted with appropriate precautions against spontaneous exothermic decomposition.

\section{Supplementary data}

Experimental procedures and spectral listings for new compounds, and other supplementary data associated with this article (found in the online version at doi:10.1016/j.tetlet.2004.08.059), are presented in the Appendix to this document.

\section{References and notes}

1. In: H. Kropf, Editors, Organische Peroxo-Verindungen, Georg Thieme Verlag, Stuttgart (1988); P.H. Dussault in C.S. Dussault Foote, J.S. Valentine, A. Greenberg and J.F. Liebman, editors, Active Oxygen in Chemistry, Blackie A\&P, London (1995), pp. 141-203.
2. P.H. Dussault, A.D. George and T.K. Trullinger, Bioorg. Med. Chem. Lett. 9 (1999), pp. 3255-3258.

3. H.-G. Brünker and W. Adam, J. Am. Chem. Soc. 117 (1995), pp. 3976-3982; S.-i. Murahashi, T. Naota, T. Kuwabara, T. Saito, H. Kumobayashi and S. Akutagawa, $J$. Am. Chem. Soc. 112 (1990), pp. 7820-7822.

4. Intermolecular reactions of tertiary epoxides are well established: W.H. Richardson and R.S. Smith, J. Org. Chem. 33 (1968), pp. 3882-3885; Y. Higuchi, K. Matsuyama and T. Komai, Bull. Chem. Soc. Jpn. 61 (1988), pp. 18211823.

5. T. Shioiri in B.M. Trost and I. Fleming, editors, Comprehensive Organic Synthesis Vol. 6, Pergamon, Oxford (1988), pp. 795-828.

6. L.L. Smith and F.L. Hill, J. Chromatogr. 66 (1972), pp. 101-109.

7. D.A. Casteel, Nat. Prod. Rep. 16 (1999), pp. 55-73.

8. W. Kirmse, Eur. J. Org. Chem. (2002), pp. 2193-2256.

9. H. Kropf and W. Nurnburg In: H. Kropf, Editors, Methods in Organic Chemistry: Organische Peroxo-Verbindungen Vol. E13, George Thieme Verlag, Stuttgart (1988), pp. 1068-1084; C.W. Jefford, J.C. Rossier and J. Boukouvalas, J. Chem. Soc., Chem. Commun. (1986), pp. 17011702. 


\title{
Experimental/Supporting Information
}

\section{Curtius rearrangements and Wolff homologations of functionalized peroxides.}

\author{
Patrick H. Dussault* and Chunping Xu \\ Department of Chemistry, University of Nebraska-Lincoln, Lincoln, NE 68588-0304 \\ pdussault1@unl.edu
}

General experimental conditions have been described. ${ }^{1}$ NMR spectra were acquired in $\mathrm{CDCl}_{3}$ unless otherwise indicated.

4-tert-Butyldioxy butanoic acid (1a): To a $0^{\circ} \mathrm{C}$ solution of $\mathrm{KMnO}_{4} \quad(7.32 \mathrm{mmole}$, $1.16 \mathrm{~g}$ ) in $25 \mathrm{~mL}$ water were added, in one portion, a solution of 1,1-dimethylethyl 4pentenyl peroxide ${ }^{2}(0.268 \mathrm{~g}, 1.83 \mathrm{mmol})$, acetic acid $(2 \mathrm{~mL})$, and a catalytic amount of benzyl triethyl ammonium chloride in $10 \mathrm{~mL}$ methylene dichloride. After $5 \mathrm{~h}$, the reaction was quenched by slow addition of sodium sulfite $(1.3 \mathrm{~g})$, followed by a solution of concentrated $\mathrm{HCl}(1.7 \mathrm{~mL})$ in water $(3 \mathrm{~mL})$. After $10 \mathrm{~min}$, the mixture was poured into a mixture of $\mathrm{CH} 2 \mathrm{Cl} 2(40 \mathrm{~mL})$ and water $(20 \mathrm{~mL})$. The separated organic layer was washed with water and dried with sodium sulfate. The solvent was evaporated and the residue was purified by 225:25:1 (Hexane/isopropanol/acetic acid) to furnish $215 \mathrm{mg}$ of the peroxyacid (72\%): ${ }^{1} \mathrm{H} \operatorname{NMR}(500 \mathrm{MHz})$ 3.95(t, 6.1, 2H), 2.45(t, 7.4, 2H), 1.89$1.94(\mathrm{~m}, 2 \mathrm{H}), 1.20(\mathrm{~s}, 9 \mathrm{H}) ;{ }^{13} \mathrm{C}(100 \mathrm{Mhz}) 80.2,73.5,26.3,25.3,23.1$ (the carboxyl was barely observable even using acquisition delays); IR(NaCl) 3500-3000 (b), 2978, 2933, 1711, 1364, 1243, $1196 \mathrm{~cm}^{-1}$; HR-FAB: calcd. for $\mathrm{C}_{8} \mathrm{H}_{16} \mathrm{O}_{4}[\mathrm{M}+\mathrm{H}]^{+}$: 177.1128. Found: 177.1119

3,5,5-Trimethyl-1,2-dioxolane-3-acetic acid (2a) was prepared using a reported procedure. $^{3}$

1-(tert-Butyldioxy)-cyclohexane carboxylic acid (3a)

1-(tert-Butyldioxy)-cyclohexane methanol: A solution of $11.61 \mathrm{~g}(67.3 \mathrm{mmol}) \mathrm{mCPBA}$ was dissolved in $80 \mathrm{~mL}$ dry methylene chloride and cooled to $0{ }^{\circ} \mathrm{C}$. $3.60 \mathrm{~g}(37.4 \mathrm{mmol})$ methylene cyclohexane in $10 \mathrm{~mL}$ methylene chloride was added slowly. The reaction was stirred at $0^{\circ} \mathrm{C}$ for 2 hours, the white crystals were filtered and washed with pentane. To a $0{ }^{\circ} \mathrm{C}$ solution of the combined filtrates was slowly added tert-butyl hydroperoxide $\left(11 \mathrm{~mL}, 5-6 \mathrm{M}\right.$ in nonane), followed by $\mathrm{BF}_{3} \mathrm{OEt}_{2}(1 \mathrm{~mol} \%)$. The reaction mixture was slowly brought to RT, stirred for $30 \mathrm{~min}$, and then quenched into $10 \%$ aq. KOH. The ether extracts were washed with water and dried with sodium sulfate. The residue obtained after concentration was purified by column chromatography (10-15\% EA/hex) to furnish 5.68g $(75 \%)$ of the peroxide as a colorless liquid: $\mathrm{R}_{\mathrm{f}}=0.55(20 \% \mathrm{EA} / \mathrm{hex}) ;{ }^{1} \mathrm{H}$ NMR (400 MHz) 3.58(d, 6.34, 2H), 2.24(t, 6.40,1H), 1.26(s,9H), 1.21-1.80(10H); ${ }^{13} \mathrm{C}$ NMR (100 MHz) 81.2, 78.9, 67.7, 30.3, 26.6, 26.0, 21.7; IR(NaCl): 3352(broad), 2931, 2858, 1457,1362, 1196, 1043, 874, $668 \mathrm{~cm}^{-1}$. HREI calc. For $\mathrm{C}_{11} \mathrm{H}_{22} \mathrm{O}_{3}(\mathrm{M}+)$ : 202.1569 . Found: 202.1562. 
To a solution of $2.01 \mathrm{~g}(9.9 \mathrm{mmol})$ of the tert-butylperoxycyclohexane methanol in $30 \mathrm{~mL}$ acetone was dropwise added Jones's reagent until the solution no longer remained bluegreen. Isopropanol was then added to quench any remaining $\mathrm{Cr}(\mathrm{VI})$ and the solution was filtered through Celite. The dried $\left(\mathrm{Na}_{2} \mathrm{SO}_{4}\right)$ solution was concentrated in vacuo and the residue purified by column chromatography using hexane/isopropanol/acetic $\operatorname{acid}(225: 25: 1)$ to furnish $2.10 \mathrm{~g}(98 \%)$ of the acid as white crystals: $\mathrm{mp} \mathrm{78-104}$ (decomposes); $\mathrm{R}_{\mathrm{f}}=0.3$ (hexane/isopropanol/acetic acid 225:25:1); ${ }^{1} \mathrm{H}$ NMR $(500 \mathrm{MHz})$ 1.35-2.00(10H), 1.32(s, 9H); ${ }^{13} \mathrm{C}$ NMR (125 MHz) 175.4, 84.0, 81.2, 30.5, 26.6, 25.0, 21.1; IR(NaCl) 2977, 2936, 2860, 1714, 1449, 1363, 1247, 1197, 1158, 1066, $885 \mathrm{~cm}^{-1}$.

\section{2-(tert-Butyldioxy) octanoic acid (4a)}

2-t-butylperoxyoctanol: To a room temperature solution of $2.1 \mathrm{~mL}(23 \mathrm{mmol}) 1,2-$ epoxyoctane in $20 \mathrm{~mL}$ methylene chloride was added tert-butyl hydroperoxide $(6.0 \mathrm{~mL}$, $35 \mathrm{mmol}, 5-6 \mathrm{M}$ in nonane) followed by $\mathrm{BF}_{3} \mathrm{OEt}_{2}(0.025 \mathrm{~mL})$. After $0.5 \mathrm{~h}$, solvent was removed in vacuo and the residue was purified by column chromatography using $5 \% \mathrm{EA} /$ hex as eluting solvent to afford $3.71 \mathrm{~g} \mathrm{(73 \% )}$ of 2-(tert-butyldioxy)-1-octanol: $\mathrm{R}_{\mathrm{f}}=$ 0.33( 10\% EA/hex); ${ }^{1} \mathrm{H}$ NMR (500 MHz) 3.96-3.98(1H), 3.74(dd, 2.8, 12.0, 1H ), $3.60(\mathrm{dd}, 5.7,12.0,1 \mathrm{H}), 2.47(\mathrm{br} \mathrm{s}, 1 \mathrm{H}), 1.22(\mathrm{~s}, 9 \mathrm{H}), 1.20-1.52(10 \mathrm{H}), 0.84(\mathrm{t}, 6.7,3 \mathrm{H}) ;{ }^{13} \mathrm{C}$ NMR (125 MHz) 84.2, 80.4, 64.8, 31.6, 29.3, 29.1, 26.3, 25.7, 22.5, 13.9; IR(NaCl) 3434(br), 2929, 2859, 1462, 1384, 1363, 1196, $1042 \mathrm{~cm}^{-1}$.

To a room temperature solution of 2-t-butylperoxyoctanol $(2.12 \mathrm{~g})$ in $30 \mathrm{~mL}$ acetone was dropwise added Jones' reagent until the red color of $\mathrm{Cr}(\mathrm{VI})$ persisted. A small excess of reagent was added and the reaction stirred for an additional $10 \mathrm{~min}$. The reaction was then quenched with isopropanol and filtered through Celite. After drying over $\mathrm{Na}_{2} \mathrm{SO}_{4}$, the solution was concentrated under reduced pressure and the residue was purified by column chromatography with hexane/isopropanol/acetic acid(225:25:1) to afford $2.14 \mathrm{~g}$ (95\%) of acid $4 \mathbf{a}$ as a white solid: $\mathrm{mp} 39-40^{\circ} \mathrm{C}$; $\mathrm{Rf}=0.2$ (hexane/isopropanol/acetic acid 225:25:1); ${ }^{1} \mathrm{H}$ NMR (400 MHz) 4.43(dd, 4.8, 8.5, 1H), 1.23-1.47(m, 16H), 1.69-1.80(m, 2H), 0.86(t, 6.8, 3H); ${ }^{13} \mathrm{C}$ NMR (100 MHz) 177.5, 82.4, 81.6, 31.4, 30.5, 28.9, 26.2, 25.4, 22.5, 14.0; IR(NaCl) 2956, 2930, 2860, 1724, 1461, 1364, $1194 \mathrm{~cm}^{-1}$. HREI calc. For $\mathrm{C}_{12} \mathrm{H}_{24} \mathrm{O}_{4}\left(\mathrm{M}^{+}\right)$: 232.1675; Found: 232.1671 .

General Procedure for generation of acyl azides:

To a solution of $0.23 \mathrm{~g}(1.31 \mathrm{mmol})$ 4-(tert-butyldioxy) butanoic acid (1a) in $16.5 \mathrm{~mL}$ acetone/water $(10: 1)$ was added $0.22 \mathrm{~mL}(1.6 \mathrm{mmol})$ triethylamine. The solution was cooled to between 0 and $-5{ }^{\circ} \mathrm{C}$ and ethyl chloroformate $0.17 \mathrm{~g}(1.6 \mathrm{mmol})$ was added dropwise. The reaction was stirred at $0^{\circ} \mathrm{C}$ for about 10 minutes, after which sodium azide $(0.17 \mathrm{~g}, 2.6 \mathrm{mmol})$ was added slowly in $2 \mathrm{~mL}$ water. After $40 \mathrm{~min}$ the reaction was quenched into ice water $(60 \mathrm{~mL})$ and the mixture extracted with diethyl ether $(3 \times 70 \mathrm{~mL})$. The combined organic layers were dried $\left(\mathrm{Na}_{2} \mathrm{SO}_{4}\right)$; the residue obtained upon concentration was used directly in the Curtius rearrangements.

General procedure for Curtius rearrangement: 
The crude acyl azide was dissolved in equal amounts of anhydrous ethanol and dry benzene and the reaction mixture was heated slowly and then held at reflux for $1.5 \mathrm{~h}$. The cooled reaction was then concentrated and the residue purified by flash chromatography.

3-tert-Butyldioxypropanamine, ethyl carbamate (1b):

$0.23 \mathrm{~g}(1.31 \mathrm{mmol})$ 4-(tert-butyldioxy) butanoic acid $1 \mathrm{a}(0.230 \mathrm{~g}, 1.31 \mathrm{mmol})$ was converted to the azide as described above. Curtius rearrangement as described above furnished $135 \mathrm{mg}$ of peroxycarbamate (47\%, two steps) as a colorless liquid: $\mathrm{R}_{\mathrm{f}}=0.35(20 \% \mathrm{EA} / \mathrm{hex}) ;{ }^{1} \mathrm{H}$ NMR(400 MHz) $4.93(\mathrm{br} \mathrm{s}, 1 \mathrm{H}), 4.05(\mathrm{q}, 7.1,2 \mathrm{H}), 3.96(\mathrm{t}, 6.0$, 2H), 3.23(appt. q, 6.3, 2H), 1.77(quint, 6.3, 2H), 1.19(s, 9H); ${ }^{13} \mathrm{C}$ NMR(100 MHz) 156.7, 80.3, 73.9, 60.6, 38.6, 28.3, 25.3, 14.6; IR(NaCl) 3339, 2979, 2934, 2875, 1701, 1534, 1364, 1256, 1197, 1048, 877, $779 \mathrm{~cm}^{-1}$; HR-FAB: calcd. for $\mathrm{C}_{10} \mathrm{H}_{21} \mathrm{NO}_{4}[\mathrm{M}+\mathrm{H}]^{+}$: 220.1550. Found: 220.1540

(3,5,5-trimethyl-1,2-dioxolane-3-methylamine, ethyl carbamates (2b) was prepared as a colorless oil (144 $\mathrm{mg}, 55 \%)$ from the corresponding acetic acid $(0.210 \mathrm{~g}, 1,2 \mathrm{mmol})$ by the procedures outlined above: $\mathrm{R}_{\mathrm{f}}=0.2(20 \% \mathrm{EtOAc} / \mathrm{Hex}) ;{ }^{1} \mathrm{H} \mathrm{NMR}(500 \mathrm{MHz}) \quad 5.13(\mathrm{br}$, $1 \mathrm{H}), 4.09(\mathrm{q}, 6.9,2 \mathrm{H}), 3.34(\mathrm{dd}, 5.6,14.0,1 \mathrm{H}), 3.26(\mathrm{dd}, 6.9,14.0,1 \mathrm{H}), 2.23(\mathrm{~d}, 12.2,1 \mathrm{H})$, $2.13(\mathrm{~d}, 12.2,1 \mathrm{H}), 1.35(\mathrm{~s}, 3 \mathrm{H}), 1.30(\mathrm{~s}, 3 \mathrm{H}), 1.29(\mathrm{~s}, 3 \mathrm{H}), 1.21(\mathrm{t}, 7.1,3 \mathrm{H}) ;{ }^{13} \mathrm{C} \mathrm{NMR}(100$ MHz) 85.6, 84.2, 60.8, 54.7, 47.5, 27.0, 25.0, 21.5, 14.6; IR: 3100-3600(br), 2979.50, 2935.65, 1701.93, 1529.99, 1456.38, 1368.96, 1243.65,1176.33, 1036.44; MS: HR-FAB: calcd. for $\mathrm{C}_{10} \mathrm{H}_{19} \mathrm{NO}_{4}[\mathrm{M}+\mathrm{H}]^{+}: 218.1393$ Found: 218.1386

1-(tert-butyldioxy)heptylamine, ethyl carbamates (4b): Conversion of 2-(tert-butyldioxy) octanoic acid $(300 \mathrm{mg}(1.3 \mathrm{mmol})$ to the azide, followed by Curtius rearrangement, furnished $213 \mathrm{mg}(60 \%$, two steps) of the ethyl carbamate as a colorless liquid: $\mathrm{R}_{\mathrm{f}}=0.33$ ( $\left.10 \% \mathrm{EA} / \mathrm{hex}\right)$; ${ }^{1} \mathrm{H}$ NMR (400 MHz) $5.36(\mathrm{~m}, 1 \mathrm{H}, \mathrm{CH}), 5.07(\mathrm{~d}, 9.3,1 \mathrm{H}$, $\mathrm{NH}), 4.11-4.16(\mathrm{~m}, 2 \mathrm{H}), 1.67-1.71(\mathrm{~m}, 1 \mathrm{H}), 1.49-1.53(\mathrm{~m}, 1 \mathrm{H}), 1.22(\mathrm{~s}, 9 \mathrm{H}), 1.23-1.40(\mathrm{~m}$, $11 \mathrm{H}), 0.86(\mathrm{t}, 6.9,2 \mathrm{H}) ;{ }^{13} \mathrm{C}$ NMR (100 MHz) 155.9, 85.4, 80.3, 60.8, 32.6, 31.6, 28.9, 26.3, 24.9, 22.5, 14.5, 14.0; IR(NaCl) 3332, 2958, 2929, 2860, 1714, 1528, 1464, 1364, 1332, 1239, 1196, $1065 \mathrm{~cm}^{-1}$; HR-FAB: calcd. for $\mathrm{C}_{14} \mathrm{H}_{29} \mathrm{NO}_{4}[\mathrm{M}+\mathrm{Li}]^{+}$: 282.2257 . Found: 282.2251 .

1-(3,5,5-Trimethyl-1,2-dioxolanyl methylamine (5): To a solution of the dioxolane acetic acid $(0.504 \mathrm{~g}, 2.87 \mathrm{mmol})$ in $27.5 \mathrm{~mL}$ acetone $/ \mathrm{H}_{2} \mathrm{O}(10 / 1)$ was slowly added $0.32 \mathrm{~g}$ (3.2 mmol) triethylamine. The solution was cooled to between 0 and $-5{ }^{\circ} \mathrm{C}$, whereupon $0.34 \mathrm{~g}(3.13 \mathrm{mmol})$ of ethyl chloroformate was added dropwise. The reaction was stirred at $0^{\circ} \mathrm{C}$ for 10 minutes, followed by slow addition of $0.374 \mathrm{~g}(5.75 \mathrm{mmol})$ sodium azide. After an additional $0.5 \mathrm{~h}$, the reaction was found to be complete (TLC) and was poured into $60 \mathrm{~mL}$ ice water and extracted with diethyl ether $(3 \times 100 \mathrm{~mL})$. The combined organic layers were dried with sodium sulfate and concentrated. The residue was redissolved in dry benzene $(15 \mathrm{~mL})$ and held at reflux for $6 \mathrm{~h}$. The reaction was cooled to $40-50^{\circ} \mathrm{C}$, whereupon concentrated hydrochloric acid, $(4 \mathrm{~mL})$ was added. After stirring for $0.5 \mathrm{~h}$, 
the reaction was cooled to RT and the benzene layer was separated and washed with water. The combined aqueous layers were treated with aq. $\mathrm{NaOH}(6 \mathrm{~N})$ to achieve a $\mathrm{pH}$ of 13 and the solution was extracted with ether $(5 \times 20 \mathrm{~mL})$. The combined organic layers were dried and concentrated to less than $10 \mathrm{~mL}$ volume. Treatment with concentrated $\mathrm{HCl}$ led to precipitation of white crystals which were filtered and dried: $\mathrm{mp} 100-106^{\circ} \mathrm{C}$ (decomposes as red liquid); ${ }^{1} \mathrm{H}$ NMR $\left(500 \mathrm{MHz}, \mathrm{D}_{2} \mathrm{O}\right) 3.32(\mathrm{~d}, 13.5,1 \mathrm{H}) 3.07(\mathrm{~d}, 13.5$, $1 \mathrm{H}), 2.49(\mathrm{~d}, 12.8,1 \mathrm{H}), 2.43(\mathrm{~d}, 12.8,1 \mathrm{H}) \quad 1.49(\mathrm{~s}, 3 \mathrm{H}), 1.46(\mathrm{~s}, 3 \mathrm{H}), 1.42(\mathrm{~s}, 3 \mathrm{H}) ;{ }^{13} \mathrm{C}$ NMR(125 MHz, DMSO) 83.9, 83.2, 54.7, 444, 26.9, 24.4, 20.8; HR-FAB: calcd. for $\mathrm{C}_{7} \mathrm{H}_{15} \mathrm{NO}_{2}[\mathrm{M}+\mathrm{H}]^{+}: 146.1182$ Found: 146.1182

\{2-phenyl-1-[(3,5,5-trimethyl-[1,2]-dioxolane-3-methyl)-carbamoyl]-ethyl\}carbamic acid benzyl ester (6): To a solution of $114.2 \mathrm{mg}(0.381 \mathrm{mmol}) \mathrm{Cbz}-\mathrm{Phe}-\mathrm{COOH}$ and $62 \mathrm{mg}(0.46 \mathrm{mmol})$ 1-hydroxybenzotriazole in $10 \mathrm{ml}$ distilled THF was added $77 \mathrm{mg}$ (0.53 mmol) 3-aminomethyl-3,5,5-trimethyl-1,2-Dioxolane. The mixture was cooled to $0{ }^{\circ} \mathrm{C}$, whereupon $94.3 \mathrm{mg}(0.457 \mathrm{mmol})$ of DCC was added. The reaction was stirred 30 min at $0^{\circ} \mathrm{C}$ and then warmed to RT and stirred overnight. The precipitate was removed by filtration and the filtrate concentrated. The residue was was purified by flash chromatography (50\% EtOAc/Hex) to afford $138 \mathrm{mg}(85 \%)$ of the amide 6 :

$\mathrm{R}_{\mathrm{f}}=0.39(50 \% \mathrm{EA} / \mathrm{hex}) ;{ }^{1} \mathrm{H}$ NMR (500 MHz) 7.14-7.32(10H), 6.49 (bs, 0.5H), 6.41 (bs, $0.5 \mathrm{H}) ; 5.39-5.41(1 \mathrm{H}), 4.99-5.06(2 \mathrm{H}), 4.46(\mathrm{br}, \mathrm{s}, 1 \mathrm{H}), 3.26-3.42(2 \mathrm{H}), 3.04-3.11(2 \mathrm{H})$, $2.01-2.12(2 \mathrm{H}), 1.32(\mathrm{~s}, 1.5 \mathrm{H}), 1.31(\mathrm{~s}, 1.5 \mathrm{H}), 1.21(\mathrm{~s}, 3 \mathrm{H}), 1.20(\mathrm{~s}, 1.5 \mathrm{H}), 1.10(\mathrm{~s}, 1.5 \mathrm{H}) ;{ }^{13} \mathrm{C}$ NMR (125 MHz), 171.2, 171.1, 155.9, 136.4, 136.3, 136.1,129.27,129.25,128.70,128.66, 128.5,128.1,128.00,127.98, 127.04, 127.02, 85.22, 85.18, 84.2, 67.0, 56.4, 54.90, 54.87, 45.8, 38.6, 27.01, 26.95, 24.95, 24.92, 21.5, 21.3; IR: 3100-3600(br), 1654.80, 1540.96, 1455.66, 1259.38668.67, 650.14 $\mathrm{cm}^{-1}$; MS: HR-FAB: calcd. for $\mathrm{C}_{24} \mathrm{H}_{30} \mathrm{~N}_{2} \mathrm{O}_{5}[\mathrm{M}+\mathrm{Li}]^{+}$: 433.2315 Found: 433.2299

5-(tert-Butyldioxy)-1-diazo-2-pentanone (1c): A solution of 4-(tert-butyldioxy) butanoic acid $(0.53 \mathrm{~g}, 3 \mathrm{mmol})$ in $20 \mathrm{~mL}$ methylene chloride was cooled to $-5^{\circ} \mathrm{C}$. Triethylamine $(0.63 \mathrm{~mL}, 1.5 \mathrm{eq}$. ) was added dropwise, followed by ethyl chloroformate $(0.49 \mathrm{~g}, 1.5 \mathrm{eq}$. $)$. The reaction was stirred for 1 hour at $-5^{\circ} \mathrm{C}$, followed by dropwise addition of ethereal diazomethane $(10 \mathrm{~mL}$, about $10 \mathrm{mmol})$ The reaction mixture was allowed to warm to room temperature and stirred for 2 hours. Solvent was removed under reduced pressure and the residue was purified by flash chromatography with $20 \%$ EA/hex as eluting solvent to afford $470 \mathrm{mg}(78 \%)$ of the diazoketone as a yellow liquid: $\mathrm{R}_{\mathrm{f}}=0.46(40 \% \mathrm{EA} / \mathrm{hex}) ;{ }^{1} \mathrm{H} \mathrm{NMR}(500 \mathrm{MHz})$ 5.26( br s,1H), 3.96(t, 6.1, 2H), 2.40 (br s, $2 \mathrm{H}), 1.94$ (quint, $\mathrm{J}=6.8,2 \mathrm{H}), 1.23(\mathrm{~s}, 9 \mathrm{H}) ;{ }^{13} \mathrm{C} \mathrm{NMR}(125 \mathrm{MHz}) 194.3,80.2,73.8,54.4$, 37.4, 26.3, 23.5; IR(NaCl) 2978, 2103,1642,1363,1195 cm $\mathrm{C}_{9} \mathrm{H}_{16} \mathrm{~N}_{2} \mathrm{O}_{3}[\mathrm{M}+\mathrm{H}]^{+}:$201.1240. Found: 201.1244

1-(3,5,5-Trimethyl-1,2-dioxolan-3-yl)-3-diazo-2-propanone (2c) was prepared as a yellow liquid (93 $\mathrm{mg}, 82 \%)$ from acid $\mathbf{2 a}$ by the standard procedure described above: $\mathrm{R}_{\mathrm{f}}=$ 0.30( 30\% EA/hex); ${ }^{1} \mathrm{H}$ NMR(400 MHz) 5.43(br s, 1H), 2.73(d, 13.8, 1H), 2.56(d, 13.8, $1 \mathrm{H}), 2.46(\mathrm{~d}, 12.3,1 \mathrm{H}), 2.21(\mathrm{~d}, 12.3,1 \mathrm{H}) 1.41(\mathrm{~s}, 3 \mathrm{H}), 1.36(\mathrm{~s}, 3 \mathrm{H}), 1.32(\mathrm{~s}, 3 \mathrm{H}) ;{ }^{13} \mathrm{C}$ NMR(125 MHz) 192.1, 84.8, 84.1, 57.1, 56.2, 50.2, 27.1, 25.6, 23.9; IR(NaCl) 2978, 
2105, 1638, 1367, $1311 \mathrm{~cm}^{-1}$; HR-FAB: calcd. for $\mathrm{C}_{9} \mathrm{H}_{14} \mathrm{~N}_{2} \mathrm{O}_{3}[\mathrm{M}+\mathrm{H}]^{+}: 199.1083$ Found: 199.1079

2-(1-tert-Butyldioxy)cyclohexyl)-1-diazo-2-ethanone (3c): To a solution of $200 \mathrm{mg}$ (0.9mmol) 1-(tert-butyldioxy)-cyclohexane carboxylic acid in $15 \mathrm{~mL}$ dry methylene chloride at room temperature was dropwise added $0.16 \mathrm{~mL}(1.85 \mathrm{mmol})$ oxalyl chloride, followed by one drop of DMF. The reaction was stirred at RT for $4 \mathrm{~h}$, and then concentrated. The residue was redissolved in $15 \mathrm{~mL}$ dry methylene chloride, cooled downed to $0^{\circ} \mathrm{C}$, and $10 \mathrm{~mL}$ (about $3 \mathrm{mmol}$ ) ethereal diazomethane was added slowly. The reaction solution was stirred at $0^{\circ} \mathrm{C}$ for $30 \mathrm{~min}$, brought to $\mathrm{RT}$, and the concentrated. The residue was purified by flash chromatography (5\% EA/hex) to afford $167 \mathrm{mg}(75 \%)$ of diazoketone as a yellow oil: $\quad \mathrm{R}_{\mathrm{f}}=0.44(10 \% \mathrm{EA} / \mathrm{Hex}) ;{ }^{1} \mathrm{H}$ NMR $(500 \mathrm{MHz}) 5.75(\mathrm{br}, \mathrm{s}$, $1 \mathrm{H}), 1.51-1.87(\mathrm{~m}, 10 \mathrm{H}), 1.28(\mathrm{~s}, 9 \mathrm{H}) ;{ }^{13} \mathrm{C}$ NMR $(125 \mathrm{MHz}) 199.3,86.6,79.5,52.1,30.3$, 26.7, 25.2, 21.3; IR(NaCl) 2978, 2938, 2860, 2102, 1643, 1448, 1338, 1195, 1146, 1009, 968, 883, 809; HR-FAB: calcd. for $\mathrm{C}_{12} \mathrm{H}_{20} \mathrm{~N}_{2} \mathrm{O}_{3}[\mathrm{M}+\mathrm{H}]^{+}: 241.1553$. Found: 241.1546

3-(tert-Butyldioxy-1-diazo-2-nonanone (4c) was prepared as a yellow liquid (154 $\mathrm{mg}$, $70 \%$ ) from 2-(tert-butyldioxy) octanoic acid $(200 \mathrm{mg}, 0.86 \mathrm{mmol})$ by a similar procedure as for diazoketone 3c.: $\mathrm{R}_{\mathrm{f}}=0.45(10 \% \mathrm{EA} / \mathrm{hex}) ;{ }^{1} \mathrm{H}$ NMR $(400 \mathrm{MHz}) \quad 5.78(\mathrm{br} \mathrm{s}, 1 \mathrm{H})$, 4.30(m, 1H) 1.24-1.70(m, 19H), 0.87(t, 6.70, 3H); ${ }^{13} \mathrm{C}$ NMR (100 MHz) 196.9, 88.2, 81.2, 52.6, 31.5, 31.3, 29.1, 26.3, 25.6, 22.5, 14.0; IR (NaCl) 2929, 2859, 2105, 1642, 1354, $1193 \mathrm{~cm}^{-1}$; HR-FAB: calcd. for $\mathrm{C}_{13} \mathrm{H}_{24} \mathrm{~N}_{2} \mathrm{O}_{3}[\mathrm{M}+\mathrm{H}]^{+}:$257.1866. Found: 257.1873.

5- tert-Butyldioxy pentanoic acid, methyl ester (1d): To a solution of $40 \mathrm{mg}(0.20$ $\mathrm{mmol}$ ) 5-t-butyldioxy-1-diazo-2-pentenone in $5 \mathrm{~mL}$ methanol and under nitrogen was added triethylamine $(0.03 \mathrm{~mL}, 0.21 \mathrm{mmol})$, followed by silver benzoate $(5 \mathrm{mg}$, appx. 0.1 equiv.) The reaction was stirred at RT for $0.5 \mathrm{~h}$, filtered through Celite, and concentrated. The residue was purified by column chromatography (10\% EA/hex) to afford $40 \mathrm{mg}$ $(>95 \%)$ of the methyl ester as a colorless liquid: $\mathrm{R}_{\mathrm{f}}=0.65$ (20\% EA/hex); ${ }^{1} \mathrm{H}$ NMR(500 $\mathrm{MHz}) \quad 3.91(\mathrm{t}, 6.3,2 \mathrm{H}), 3.64(\mathrm{~s}, 3 \mathrm{H}), 2.31(\mathrm{t}, 7.3,2 \mathrm{H}), 1.62-1.68(\mathrm{~m}, 4 \mathrm{H}), 1.20(\mathrm{~s}, 9 \mathrm{H}) ;{ }^{13} \mathrm{C}$ NMR(125 MHz), 173.9, 80.1, 74.4, 51.5, 33.8, 27.4, 26.3, 21.8; IR(NaCl) 2977, 2952, $1740,1362,1242,1197,1169 \mathrm{~cm}^{-1}$.

3-(3,3,5-Trimethyl-1,2-dioxolan-3-yl) propanoic acid, methyl ester (2d) was prepared as a colorless liquid $(20 \mathrm{mg},>95 \%)$ from diazoketone $\mathbf{2 c}$ by a similar procedure as for 1d: $\mathrm{R}_{\mathrm{f}}=0.50(25 \% \mathrm{EA} / \mathrm{hex}) ;{ }^{1} \mathrm{H}$ NMR $(400 \mathrm{MHz}) 3.67(\mathrm{~s}, 3 \mathrm{H}), 2.34-2.48(2 \mathrm{H}), 2.21(\mathrm{~d}$, $12.1,1 \mathrm{H}), 2.15(\mathrm{~d}, 12.1,1 \mathrm{H}) 2.14(\mathrm{ddd}, 6.0,10.4,14.1,1 \mathrm{H}) 1.86(\mathrm{ddd}, 6.0,10.4,14.1,1 \mathrm{H}$ ), 1.36(s, 3H), 1.33(s, 3H), 1.30(s, 3H); ${ }^{13} \mathrm{C}$ NMR (125 MHz) 173.9, 85.1, 83.8, 57.5, 51.7, 34.2, 29.3, 26.8, 26.0, 23.5; IR(NaCl) 2975, 2930, 1739, 1453, 1367, 1304, 1244, 1197, $1167 \mathrm{~cm}^{-1}$.

2-[1-(tert-Butyldioxy)cyclohexyl] acetic acid, methyl ester (3d): A solution of 100mg 1-(1-tert-butyldioxy)cyclohexyl)- 2-diazo-ethanone and $0.5 \mathrm{~mL}$ acetic acid in dry methanol $(15 \mathrm{~mL})$ was irradiated for $4 \mathrm{~h}(254 \mathrm{~nm}$, Rayonet circular reactor) in a quartz tube. The solvent was removed in vacuo, and the residue was purified by column chromatography (5\% EA/hex) to afford $76 \mathrm{mg}(75 \%)$ of methyl ester as a colorless oil: 
$\mathrm{R}_{\mathrm{f}}=0.46(10 \% \mathrm{EA} / \mathrm{Hex}) ;{ }^{1} \mathrm{H}$ NMR (400 MHz) 3.64(s, 3H), 2.59(s, 2H), 1.42-1.95(m, $10 \mathrm{H}), 1.21(\mathrm{~s}, 9 \mathrm{H}) ;{ }^{13} \mathrm{C} \mathrm{NMR}(100 \mathrm{MHz}) 171.8,79.4,78.4,51.2,43.3,33.1,26.6,25.5$, 21.8; IR(NaCl) 2977, 2934, 2861, 1740, 1440, 1362, 1198, 1129, 1016, $885 \mathrm{~cm}^{-1}$.HREI calc for $\mathrm{M}^{+}$: 244.1675; Found: 244.1665 .

3-(tert-Butyldioxy)-nonanoic acid, methyl ester (4d) was prepared as a colorless liquid (34 mg, >80\%) from) 3-(tert-butyldioxy)-1-diazo-2-nonanone (40mg, 0.156mmol) by a similar procedure as for $\mathbf{3 d}$ except that irradiation was conducted for only $3 \mathrm{~h}$ : $\mathrm{R}_{\mathrm{f}}=0.44$ (10\% EA/hex); ${ }^{1} \mathrm{H}$ NMR (400 MHz); 4.36(m, 1H), 3.67(s, 3H), 2.76(dd, 6.7, 15.1, 1H), $2.38(\mathrm{dd}, 5.7,15.1,2 \mathrm{H}), 1.23-1.57(\mathrm{~m}, 12 \mathrm{H}), 1.21(\mathrm{~s}, 9 \mathrm{H}), 0.87(\mathrm{t}, 6.7,3 \mathrm{H}) ;{ }^{13} \mathrm{C} \mathrm{NMR}(100$ MHz) 172.4, 80.19, 80.17, 51.5, 38.9, 32.9, 31.7, 29.3, 26.3, 25.5, 22.6, 14.1; IR(NaCl) $2954,2930,2858,1742,1436,1362,1246,1197,1167 \mathrm{~cm}^{-1}$.

\section{References:}

${ }^{1}$ Dussault, P. H.; Eary, C. T.; Lee, R. J.; Zope, U. R. J. Chem. Soc., Perkins Trans. 1 1999, 2189-2204.

${ }^{2}$ Bourgeois, M. J.; Maillard, B.; Montaudon, E. Tetrahedron 1986, 42, 5309-5320.

${ }^{3}$ Dussault, P. H.; Liu, X. Org. Lett. 1999, 1, 1391-1393. 